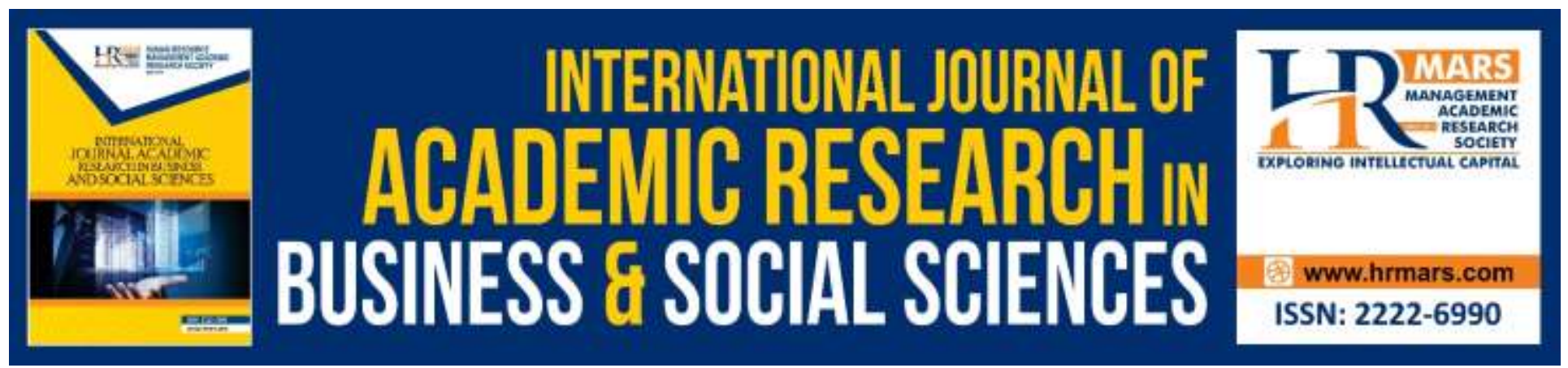

\title{
Scientific Publishing for Students in Libyan Universities from Perspectives of Faculty Members and Postgraduate Students
}

Abdul Ghafar Mansor Mohamad Mohamad, Marwan Ibrahim Alfadhli, Nikaela Yolanda Wilson, Rima Subhi Taher

To Link this Article: http://dx.doi.org/10.6007/IJARBSS/v10-i6/7258

DOI:10.6007/IJARBSS/v10-i6/7258

Received: 04 April 2020, Revised: 07 May 2020, Accepted: 29 May 2020

Published Online: 03 June 2020

In-Text Citation: (Mohamad et al., 2020)

To Cite this Article: Mohamad, A. G. M. M., Alfadhli, M. I., Wilson, N. Y., Taher, R. S. (2020). Scientific Publishing for Students in Libyan Universities from Perspectives of Faculty Members and Postgraduate Students. International Journal of Academic Research in Business and Social Sciences, 10(6), 21-34.

Copyright: (c) 2020 The Author(s)

Published by Human Resource Management Academic Research Society (www.hrmars.com)

This article is published under the Creative Commons Attribution (CC BY 4.0) license. Anyone may reproduce, distribute, translate and create derivative works of this article (for both commercial and non-commercial purposes), subject to full attribution to the original publication and authors. The full terms of this license may be seen at: http://creativecommons.org/licences/by/4.0/legalcode

Vol. 10, No. 6, 2020, Pg. 21 - 34

Full Terms \& Conditions of access and use can be found at http://hrmars.com/index.php/pages/detail/publication-ethics 


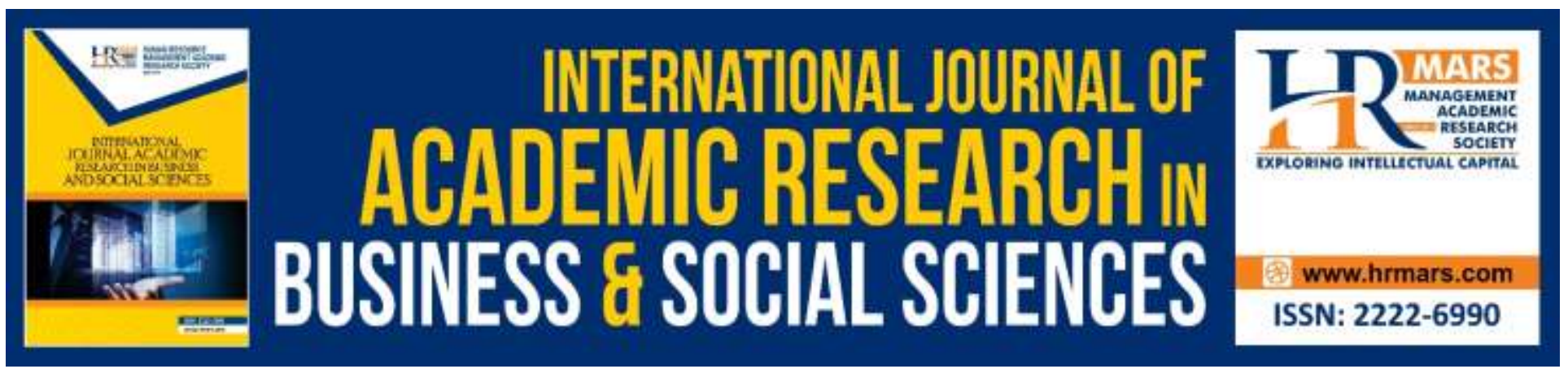

\title{
Scientific Publishing for Students in Libyan Universities from Perspectives of Faculty Members and Postgraduate Students
}

\section{${ }^{1}$ Abdul Ghafar Mansor Mohamad Mohamad, ${ }^{2}$ Marwan Ibrahim Alfadhli, ${ }^{3}$ Nikaela Yolanda Wilson, ${ }^{4}$ Rima Subhi Taher}

${ }^{1}$ Higher Institute of Science and Technology, Gharyan, ${ }^{2}$ Financial Accounting Department, Elmerqib University, Libya, ${ }^{3}$ Faculty of Economics, Belgrade University, Belgrade, Serbia, ${ }^{4}$ Faculty of Philology,

Belgrade University, Belgrade, Serbia.

Email: marwanalfadhli1988@gmail.com

\begin{abstract}
Due to the scientific research at present is considered one of the important and major functions performed by both faculty members and postgraduate students, in order to contribute to the dissemination of knowledge and solutions to the various problems facing the society, and also to the advancement of Libyan universities. This paper aims to identify the difficulties faced the students in the Libyan universities in scientific research from perspectives of faculty members and postgraduate students, and to know the difficulties that hinder the scientific research in these universities and work to confront them. In addition, the researchers used the SPSS method to reach the objectives of this paper. A questionnaire was distributed to faculty members and postgraduate students in order to obtain data that contribute to the objectives of this paper. This paper concluded that faculty members contribute to training students on scientific research, and there is cooperation between the supervisor and the student in relation to the thesis presented by students. Moreover, Libyan scientific journals publish the researches for students whose research terms meet all conditions of scientific research. Research recommended that work to training the postgraduate students on scientific research skills in what is related to all of his fields, as well as how to write, present and interpret results, proposals and recommendations, and establish a special and independent department for scientific publishing in Libyan universities.
\end{abstract}

Keywords: Scientific Publishing, Libyan Universities, Faculty Members, Postgraduate Students.

\section{Introduction}

The university is a productive institution working to spread knowledge, prepare human competencies and industry generations, and work to create an advanced generation intellectually, scientifically and culturally. Also the university is considered scientific community concerned with scientific research, and specializes in the teaching, conducting scientific research and community 
INTERNATIONAL JOURNAL OF ACADEMIC RESEARCH IN BUSINESS AND SOCIAL SCIENCES Vol. 10, No. 6, June, 2020, E-ISSN: 2222-6990 @ 2020 HRMARS

service (Alhrahsha, 2013). Where scientific research is important at the present time, because the development of countries and achieve their goals and strength depends on what they accomplish and progress of scientific research (Muhaisen, 2011).

Thus, scientific research becomes a necessity that cannot be overstep for many Arab countries, including Libya, because it is the only way to bridge the gap that separates developing countries from the developed world. On the one side, and on the other side, we can maintain and strengthen our national achievements and preserve our identity and our entity only by having the corner of scientific research (Abdullah \& Shamas, 2010).

\section{Problem Statement}

The need for studies, research and the productions of science is even greater today than ever before, where science and the world are in a race to reach as much as possible the exact knowledge derived from science that guarantees human well-being and excellence in the framework of cultural competition, to reach a common understanding of the aims and purposes of scientific research, based on the wisdom of reason to guide science as an important factor in the stability of nations and their cooperation in building human civilization (Abdullah \& Shamas, 2010). As well Al-Shaibani (2018) mention that scientific research is what gives society its productive strength, which contributes to economic production, knowledge, information and other fields of creativity. That is why development experts believe that scientific research is the locomotive that drives society towards sustainable development. Moreover, the study of Amer (2018) revealed that the research professors rely on publishing their scientific research on journals Paper, as the study showed that there are difficulties that stand in the way of the use of electronic journals, which are technical difficulties, and that the individuals of the sample have a weakness in the skill of using the Internet as needed.

According to Bin Saud, the challenges of scientific research in Libya can be divided into traditional and non-traditional ones. Traditionally, these are the challenges facing scientific research in the Arab world in general, which have traditionally been mentioned in most research related to this subject. The non-traditional challenges are those that have not been addressed before, which were produced by the study of the challenges of Libyan higher education and the experience of the scientific research in Libyan universities, were divided into cultural and other security challenges, the following figure illustrates these divisions:

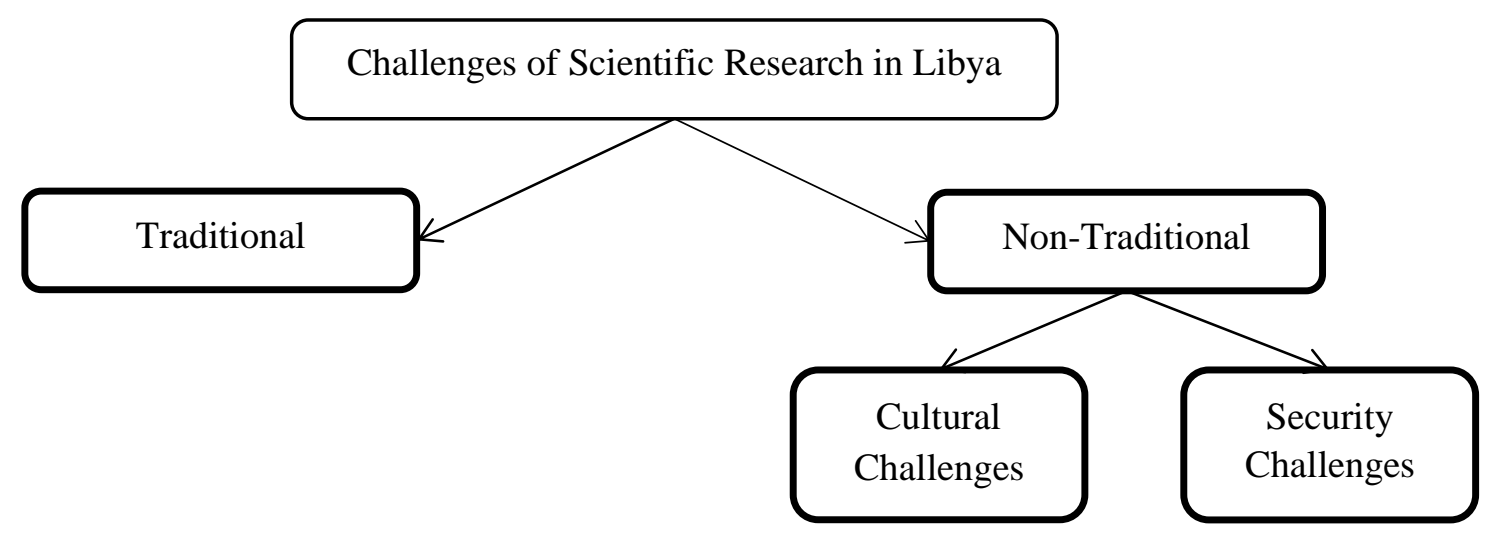

Figure 1: illustrates Challenges of Scientific Research in Libya 
Moreover, with such current circumstance of scientific publishing in Libyan Universities, this research attempts to fill this research gap by identify the difficulties faced by the Libyan universities in scientific research from perspectives faculty members and postgraduate students and work to confront them, where there is no evidence of any study which deals with scientific publishing for students in Libyan universities.

\section{Research Questions}

a) Is there a statistically significant relationship between the faculty members and the scientific publishing for students in the Libyan universities?

b) Is there a statistically significant relationship between the Libyan scientific journals and the scientific publishing for students in the Libyan universities?

c) Is there a statistically significant relationship between the arbitration and the scientific publishing for students in the Libyan universities?

\section{Research Objectives}

This paper aims to know the most important difficulties facing scientific publishing for students in Libyan universities from the viewpoint of faculty members and postgraduate students. Moreover, the importance of the study in general stems from the importance of the subject of scientific research and its role in developing and advancing Libyan universities and thus contributing to the progress of society.

a) Determine if there is a statistically significant relationship between the faculty members and the scientific publishing for students in the Libyan universities.

b) Determine if there is a statistically significant relationship between the Libyan scientific journals and scientific publishing for students in the Libyan universities.

c) Determine if there is a statistically significant relationship between the arbitration and scientific publishing for students in the Libyan universities.

\section{Research Importance}

The importance of this paper is to identify the problems facing students and researchers in the Libyan universities. This paper contributes to the detection of the most important problems and constraints facing graduate students in the Libyan universities and work to solve these problems and obstacles.

Moreover, the results of this paper may benefit researchers, students and faculty members in Libya to know the reasons that hinder the work of scientific research and also benefit officials and deanship of colleges in the Libyan universities to take appropriate measures to solve these obstacles and work on research and scientific publishing. 


\section{Literature Review}

In Jordan study of Droubi (2018) aims to shed light on the obstacles of scientific research in the field of management information systems and information technology from the point of view of those interested in this field in (Jordanian universities). The data were collected by means of a questionnaire distributed to the study sample and then analyzed by (SPSS) and (one-way ANOVA test). This research concluded that there are many obstacles that must be overcome to develop scientific research in this area, namely, financial, legal, scientific, managerial, and investment constraints. It was found that dissatisfaction with the level of scientific research in management information systems and information technology, where it was found that there is a percentage (79.9\%) dissatisfied.

While in Al Sharif (2019) conducted a research entitled The Quality of Applied Scientific Research in Libyan Universities: Realities and Challenges the future. This study aims to determine the reality of applied scientific research in Libyan universities, also to know the availability of quality indicators of applied scientific research in published research and monitor the most important obstacles to applied scientific research. This study concludes that the problem of the quality of scientific research, as the core material for the study of all scientific problems and their causes, while trying to give some of the solutions are effective and appropriate, in order to catch up with developed countries.

Also, each of Algadheeb and Almeqren (2014) did a paper in the Kingdom of Saudi Arabia entitled obstacles to scientific research in the light of a number of variables as it aims to know the obstacles facing scientific research for faculty members in the Faculty of Education at Princess Nourah bint Abdulrahman University and also identify differences by age, scientific specialization and rank Academic, marital status, number of studies completed, as well as in the period since the last academic rank was received.

\section{Research Methodology}

The researchers used the descriptive analytical approach in conducting this research, as it is considered one of the most used methods in the studies that included the same subject of the present paper, and the researchers relied on the questionnaire to analyze the results and reach the objectives of this paper. I have prepared a questionnaire specifically for this research. The questionnaire consists of 15 items, classified into 3 Axes, include (Faculty Member, Libyan Scientific Journals, and The Arbitration).

\section{Research Community and Sample Size}

The research community consisted of faculty and graduate students in Libyan universities, and the researchers selected a random sample number consisting of faculty and graduate students, where the number of the sample and respondents was (130) 
INTERNATIONAL JOURNAL OF ACADEMIC RESEARCH IN BUSINESS AND SOCIAL SCIENCES Vol. 10, No. 6, June, 2020, E-ISSN: 2222-6990 @ 2020 HRMARS

Table 1: Sample Size

\begin{tabular}{|c|c|}
\hline Respondents & Number \\
\hline Faculty Members & 23 \\
\hline Postgraduate students & 107 \\
\hline Total & 130 \\
\hline
\end{tabular}

\section{Validity and Consistency of the Questionnaire}

The researchers worked and drafted the questionnaire according to previous studies and were presented to some arbitrators with experience in the subject under study and scientific research, has been taking their observations. To ensure the validity of the questionnaire paragraphs, the researchers conducted a test to measure the compatibility between the paragraphs where the researchers relied on the coefficient (Cronbach's Alpha) because it shows the strength of consistency between the paragraphs (George \& Mallery, 2003).

As mentioned Isaac and Michael (1995) that the sample number is useful between 10-30, and Perneger, Courvoisier, Hudelson, \& Gayet-Ageron, (2015) if the number of questionnaires distributed in the test is 30 , this is useful.

Table 2: Cronbach's Alpha Test

\begin{tabular}{|l|l|l|}
\hline Variable & Number & $\begin{array}{l}\text { Cronbach's } \\
\text { Alpha }\end{array}$ \\
\hline Faculty Members & 10 & .811 \\
\hline Libyan Scientific Journals & 10 & .871 \\
\hline The Arbitration & 10 & .922 \\
\hline Total & $\mathbf{3 0}$ & $\mathbf{. 8 6 8}$ \\
\hline
\end{tabular}

The data in Table (3) indicate that the coefficient of stability for the study scale ranged between (.811-.922) the lowest stability coefficient was (.811). While the highest coefficient was (.928), the total score was (.868), this ratio is above the good. The table indicates that there is consistency between the paragraphs and according to this result can rely on the results of the questionnaire, credibility, stability and ability to reach the objectives of the study.

\section{Normal Distribution of Data}

Table 3: Normal Distribution of Data

\begin{tabular}{|l|l|}
\hline Variable & .Sig \\
\hline Faculty Members & .351 \\
\hline Libyan Scientific Journals & .455 \\
\hline The Arbitration & .569 \\
\hline
\end{tabular}

Testing the natural distribution of data shows whether the data in the questionnaire follow or not, where the researchers relied on (Kolmogorov-Smirnov Test) The result obtained from the test According to the table (4) the probability value of sig. For variables is greater than (0.05). According to the results shown in the table (4), the data follow normal distribution. 
INTERNATIONAL JOURNAL OF ACADEMIC RESEARCH IN BUSINESS AND SOCIAL SCIENCES Vol. 10, No. 6, June, 2020, E-ISSN: 2222-6990 @ 2020 HRMARS

\section{Personal data of the Research Sample}

Table 4: The Personal Data of the Research Sample

\begin{tabular}{|l|l|l|}
\hline \multirow{2}{*}{ Gender } & variable & Percentage \\
\hline \multirow{4}{*}{ Age } & Male & $54 \%$ \\
\cline { 2 - 3 } & Female & $46 \%$ \\
\hline \multirow{3}{*}{ Scientific Level } & From 20 to 30 years & $30 \%$ \\
\cline { 2 - 3 } & From 31 to 40 years & $43 \%$ \\
\cline { 2 - 3 } & More than 41 years & $\mathbf{2 7 \%}$ \\
\hline \multirow{2}{*}{ Total } & BA & $\mathbf{2 5 \%}$ \\
\cline { 2 - 3 } & M.A. & $\mathbf{4 8 \%}$ \\
\cline { 2 - 3 } & Ph.D & $\mathbf{2 7 \%}$ \\
\hline
\end{tabular}

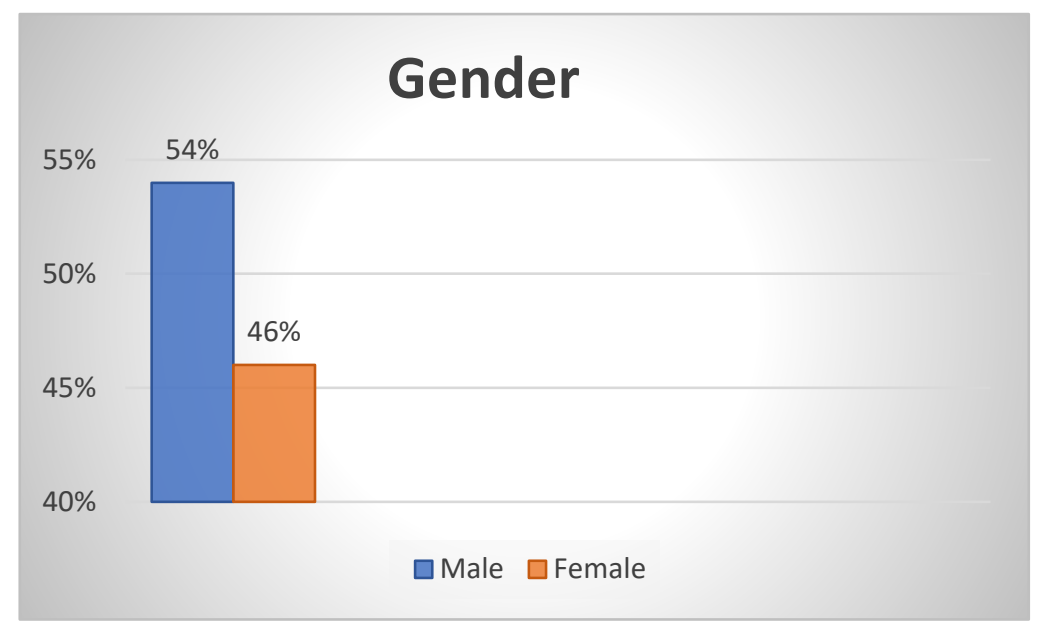

Figure 1: Shows Gender Data for the Study Sample

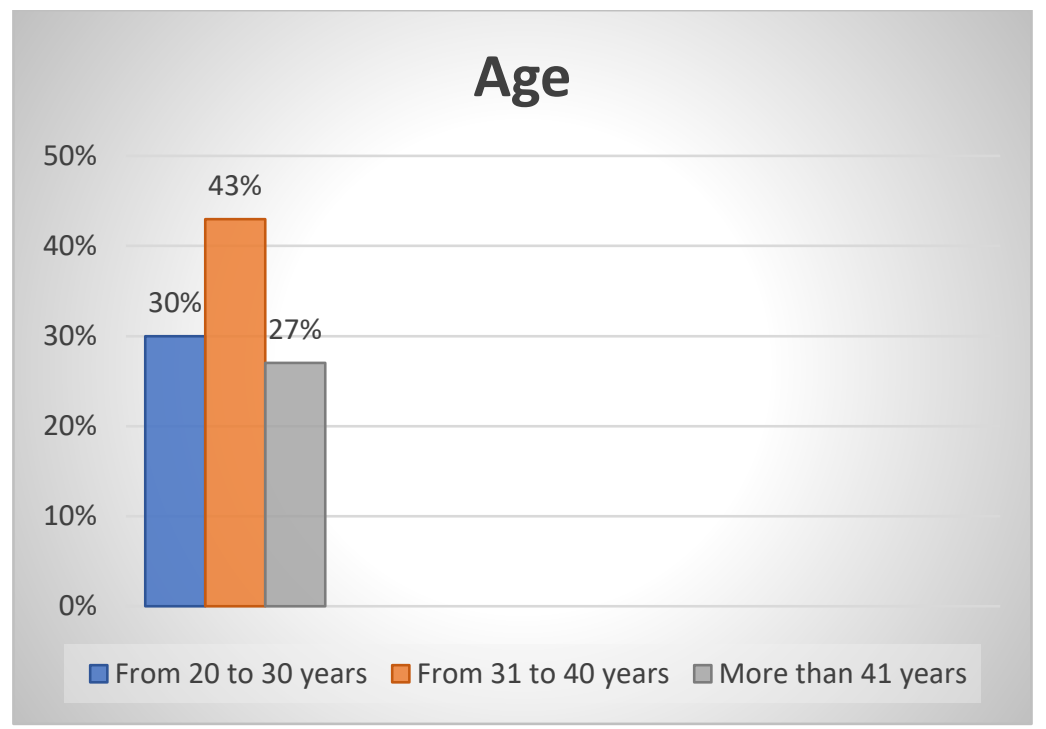

Figure 2: Shows Age Data for the Study Sample 


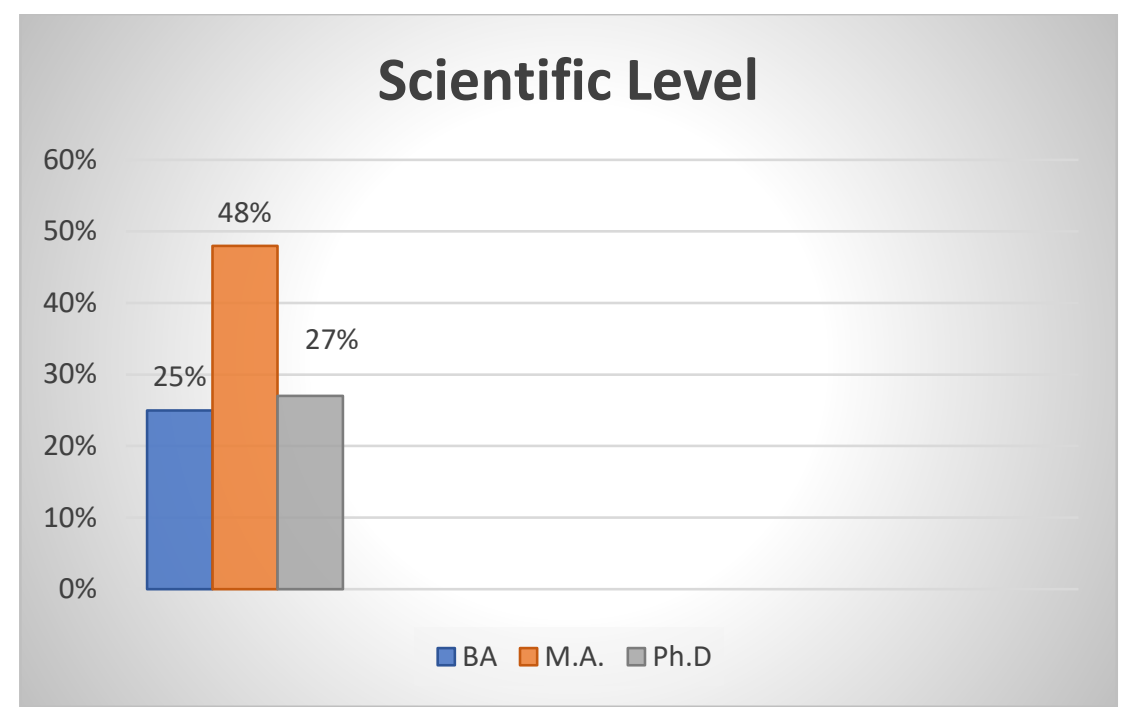

Figure 3: Shows Scientific Level Data for the Study Sample

\section{Research Framework}

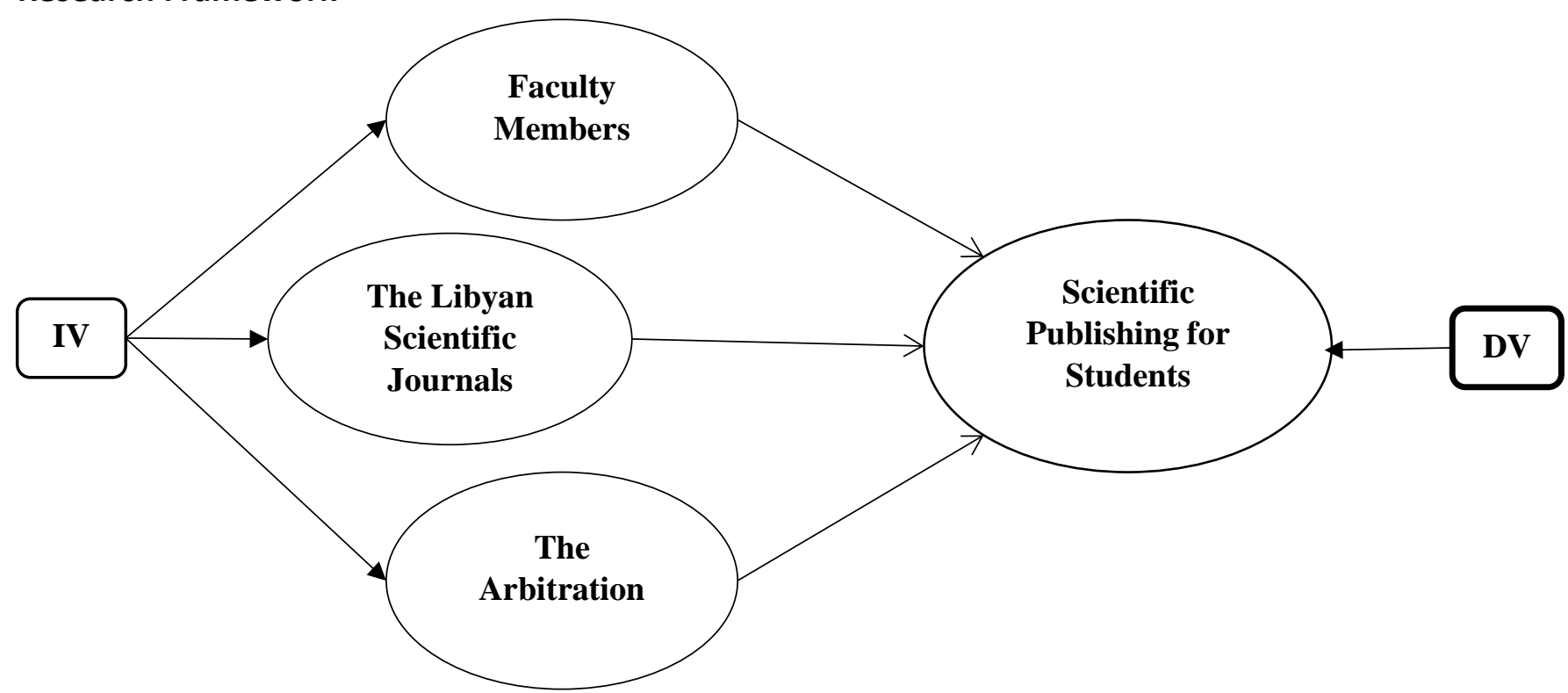

Figure 4: Research Framework

\section{Research Hypotheses}

The research hypotheses are built on the problem of the study, as it presents possible answers to the studied phenomenon, and expected solutions to the study problem, and the following assumptions were relied on:

1) There is a statistically significant relationship between the faculty members and the scientific publishing for students in the Libyan universities.

2) There is a statistically significant relationship between the Libyan scientific journals and the scientific publishing for students in the Libyan universities. 
INTERNATIONAL JOURNAL OF ACADEMIC RESEARCH IN BUSINESS AND SOCIAL SCIENCES Vol. 10, No. 6, June, 2020, E-ISSN: 2222-6990 @ 2020 HRMARS

3) There is a statistically significant relationship between the arbitration and the scientific publishing for students in the Libyan universities.

\section{Analysis of Hypotheses}

There is a statistically significant relationship between the faculty members and the scientific publishing for students in the Libyan universities.

\begin{tabular}{|l|l|l|l|}
\hline Table 5: Analysis of Items of Faculty Members Faculty Members & Mean & $\begin{array}{l}\text { Standard } \\
\text { Deviation }\end{array}$ & Sig. \\
\hline Research methodology is concerned with theoretical and practical aspects & 4.15 & .614 & 0.000 \\
\hline Faculty members contribute to training students in scientific research & 4.42 & .745 & 0.000 \\
\hline $\begin{array}{l}\text { There is cooperation between the supervisor and the student regarding the } \\
\text { submitted letter }\end{array}$ & 3.99 & 1.05 & 0.000 \\
\hline $\begin{array}{l}\text { There is a relationship between the materials required for study and } \\
\text { scientific research }\end{array}$ & 3.84 & 1.14 & 0.000 \\
\hline Teaching materials develop students' scientific research skills & 4.01 & .924 & 0.000 \\
\hline Total & $\mathbf{4 . 0 8}$ & $\mathbf{. 9 1 4}$ & $\mathbf{0 . 0 0 0}$ \\
\hline
\end{tabular}

Table 5 indicates that the overall mean was 4.08, where the lowest mean score was 3.84 for paragraph 4 (There is a relationship between the materials required for study and scientific research), and the largest mean score was 4.42 for paragraph 2 (Faculty members contribute to training students in scientific research), where this result indicates that respondents agree to this axis and that The faculty members have a positive role in the scientific publishing of students in Libyan universities, and this is confirmed by the standard deviation of .914 which is considered a good percentage.

There is a statistically significant relationship between the Libyan scientific journals and the scientific publishing for students in the Libyan universities.

Table 6 Analysis of Items of the Libyan Scientific Journals

\begin{tabular}{|l|l|l|l|}
\hline The Libyan Scientific Journals & Mean & $\begin{array}{l}\text { Standard } \\
\text { Deviation }\end{array}$ & Sig. \\
\hline $\begin{array}{l}\text { Scientific journals contribute to the publishing of research } \\
\text { for students. }\end{array}$ & 4.11 & .745 & 0.000 \\
\hline $\begin{array}{l}\text { The journals respond to researchers receiving their } \\
\text { research. }\end{array}$ & 4.21 & .457 & 0.000 \\
\hline $\begin{array}{l}\text { Scientific journals send research papers to arbitrators if } \\
\text { they receive the research from students or researchers. }\end{array}$ & 3.99 & 1.10 & 0.000 \\
\hline $\begin{array}{l}\text { The journals inform researchers of the modifications } \\
\text { required for their research. }\end{array}$ & 3.64 & .854 & 0.000 \\
\hline $\begin{array}{l}\text { Research is rejected for objective reasons and according } \\
\text { to the arbitrators' report, while the research does not } \\
\text { apply to the conditions of scientific publishing. }\end{array}$ & 3.79 & 1.15 & 0.000 \\
\hline Total & $\mathbf{3 . 9 4}$ & $\mathbf{. 8 6 1}$ & $\mathbf{0 . 0 0 0}$ \\
\hline
\end{tabular}

According to Table 6 the overall mean was 3.94, where the lowest mean score was 3.64 for paragraph 4 (The journals inform researchers of the modifications required for their research), and 
INTERNATIONAL JOURNAL OF ACADEMIC RESEARCH IN BUSINESS AND SOCIAL SCIENCES Vol. 10, No. 6, June, 2020, E-ISSN: 2222-6990 @ 2020 HRMARS

the largest mean score was 4.21 for paragraph 2 (The journals respond to researchers receiving their research), where this result indicates that most respondents agree to this axis and that The Libyan Scientific Journals have a positive role in the scientific publishing of students in Libyan universities, and this is confirmed by the standard deviation of .861 which is considered a good percentage.

There is a statistically significant relationship between the arbitration and the scientific publishing for students in the Libyan universities.

Table 7: Analysis of Items of the arbitration

\begin{tabular}{|l|l|l|l|}
\hline The Arbitration & Mean & $\begin{array}{l}\text { Standard } \\
\text { Deviation }\end{array}$ & Sig. \\
\hline $\begin{array}{l}\text { There is a short period between receiving the research and } \\
\text { responding to the student or researcher regarding } \\
\text { accepting or rejecting the research. }\end{array}$ & 4.54 & .598 & 0.000 \\
\hline $\begin{array}{l}\text { Provide students and researchers with the reasons that } \\
\text { contributed to rejecting the research in order to benefit } \\
\text { from it in subsequent research. }\end{array}$ & 4.64 & .587 & 0.000 \\
\hline $\begin{array}{l}\text { The standard for research arbitration are clear and } \\
\text { understandable to all researchers and students. }\end{array}$ & 4.31 & .487 & 0.000 \\
\hline $\begin{array}{l}\text { The arbitrators' interest in all official matters rather and } \\
\text { the essence of the research. }\end{array}$ & 3.95 & 1.02 & 0.000 \\
\hline $\begin{array}{l}\text { availability of objectivity and fairness in the arbitration } \\
\text { process of research, and Personal relationships do not } \\
\text { affect the evaluation of research and publishing } \\
\text { agreement. }\end{array}$ & 4.04 & .987 & 0.000 \\
\hline Total & $\mathbf{4 . 2 9}$ & .735 & $\mathbf{0 . 0 0 0}$ \\
\hline
\end{tabular}

According to Table 7, the overall mean was 4.29, whereby paragraph 4 (The arbitrators' interest in all official matters rather and the essence of the research) obtained the lowest mean arithmetic ratio of 3.95, and paragraph 2 (Provide students and researchers with the reasons that contributed to rejecting the research in order to benefit from it in subsequent research) had the largest arithmetic mean with a score of 4.64, and according to this result, respondents agree to this axis and that the Arbitration have a positive A role in the scientific publishing of students in Libyan universities, and this is confirmed by the standard deviation of .735, which is considered an average percentage. 
INTERNATIONAL JOURNAL OF ACADEMIC RESEARCH IN BUSINESS AND SOCIAL SCIENCES Vol. 10, No. 6, June, 2020, E-ISSN: 2222-6990 @ 2020 HRMARS

\section{Pearson Correlation}

Table 8: The Relationship Between Independent and Dependent Variables

\begin{tabular}{|c|c|c|c|}
\hline \multicolumn{4}{|c|}{ Relationship Between Faculty Members and Scientific Publishing for Students } \\
\hline \multirow[t]{3}{*}{ Faculty Members } & Pearson Correlation & 1 & $.865 * *$ \\
\hline & Sig. (2-tailed) & & .001 \\
\hline & $\mathrm{N}$ & 10 & 10 \\
\hline \multirow{3}{*}{$\begin{array}{l}\text { Scientific Publishing for } \\
\text { Students }\end{array}$} & Pearson Correlation & $.865 * *$ & 1 \\
\hline & Sig. (2-tailed) & .001 & \\
\hline & $\mathrm{N}$ & 10 & 10 \\
\hline \multicolumn{4}{|c|}{ Relationship Between the Libyan Scientific Journals and Scientific Publishing for Student } \\
\hline \multirow[t]{3}{*}{ The Libyan Scientific Journals } & Pearson Correlation & 1 & $.844^{* *}$ \\
\hline & Sig. (2-tailed) & & .001 \\
\hline & $\mathrm{N}$ & 10 & 10 \\
\hline \multirow{3}{*}{$\begin{array}{l}\text { Scientific Publishing for } \\
\text { Students }\end{array}$} & Pearson Correlation & $.844 * *$ & 1 \\
\hline & Sig. (2-tailed) & .001 & \\
\hline & $\mathrm{N}$ & 10 & 10 \\
\hline \multicolumn{4}{|c|}{ Relationship Between the arbitration and Scientific Publishing for Students } \\
\hline \multirow[t]{3}{*}{ The Arbitration } & Pearson Correlation & 1 & $.911 * *$ \\
\hline & Sig. (2-tailed) & & .001 \\
\hline & $\mathrm{N}$ & 10 & 10 \\
\hline \multirow{3}{*}{$\begin{array}{l}\text { Scientific Publishing for } \\
\text { Students }\end{array}$} & Pearson Correlation & $.911^{* *}$ & 1 \\
\hline & Sig. (2-tailed) & .001 & \\
\hline & $\mathrm{N}$ & 10 & 10 \\
\hline
\end{tabular}

**. Correlation is significant at the 0.01 level (2-tailed).

According to Table 8: The Sig. (2-tailed) for the relationship between faculty members and scientific publishing for Students is equal to .001 which is less than 0.05 and the relationship rate has reached $.865^{* *}$ which is a good degree. While the Sig. (2-tailed) of the relationship between Libyan scientific journals and scientific publication for Students was .001, which is less than 0.05, and the relationship reached $.844^{* *}$ which is a positive relationship. Moreover, the third variable for the arbitrator and their relationship to scientific publishing for Students has also reached the Sig. (2-tailed) .001 which is less than 0.05 and the degree of relationship was $.911^{* *}$ which is a strong relationship.

According to the results of the Pearson table, all Independent variables (faculty members, Libyan scientific journals, and the arbitrator) have a positive relationship with the dependent variable (scientific publishing for students).

\section{Hypothesis Results}

The first hypothesis: There is a statistically significant relationship between the faculty members and the scientific publishing for students in the Libyan universities. The results showed that the 
hypothesis is correct and that there is a relationship between the faculty members and the scientific publishing for students in the Libyan universities.

The second hypothesis: There is a statistically significant relationship between the Libyan scientific journals and the scientific publishing for students in the Libyan universities. The results showed that the hypothesis is correct and that there is relationship between the Libyan scientific journals and the scientific publishing for students in the Libyan universities.

The third hypothesis: There is a statistically significant relationship between the arbitration and the scientific publishing for students in the Libyan universities. The results showed that the hypothesis is correct and that there is a relationship between the arbitration and the scientific publishing for students in the Libyan universities.

\section{Research Results}

Scientific research is a necessity and a priority for universities, which requires accelerating the establishment of procedures and foundations for it to be a requirement for every student in Libyan universities. Furthermore, according to the study of the difficulties that students face in scientific publishing in Libyan universities, knowledge of the role of faculty members, Libyan scientific journals, and arbitration for journals and universities. According to the results of the study sample answers, the research concluded that:

i. The faculty members contribute to training students on scientific research.

ii. There is cooperation between the supervisor and the student in relation to the thesis presented by students.

iii. Some of the academic subjects are related to scientific research, and the educational materials contribute to developing the scientific research skills of students.

iv. Libyan scientific journals publish the researches for students whose research terms meet all conditions of scientific research.

v. Libyan scientific journals send research papers to arbitrators when they receive research from students and then inform the student of the period taken by arbitration.

vi. The journal informs the researcher or student of the arbitrators' report and if the paper was accepted or rejected as well as the amendments required of them.

vii. Receiving the research and responding to the student or researcher with regard to accepting or rejecting the research is within a short period, and students and researchers are provided with the reasons that contributed to rejecting the research.

viii. The arbitration is according to clear and explicit criteria and rules, in addition to that, the arbitrators enjoy objectivity and integrity in a process Research arbitration.

\section{Research Contribution}

This research derives its importance through the positive role that scientific research can contribute to the process of sustainable development. Moreover, the contribute of this paper lies in identifying the difficulties that students in Libyan universities face in scientific research from the viewpoint of faculty members and graduate students, and knowing the difficulties that hinder scientific research in these universities and work to confront them. Furthermore, another contribution is that the research sample is represented by faculty members and postgraduate students in Libyan universities, and this is what makes the research sample limited to a specific angle to reach the best result. At last, in terms of the environment, there is a shortage of studies that were 
INTERNATIONAL JOURNAL OF ACADEMIC RESEARCH IN BUSINESS AND SOCIAL SCIENCES

Vol. 10, No. 6, June, 2020, E-ISSN: 2222-6990 @ 2020 HRMARS

conducted in the environment under study and find most of the previous studies were conducted in different environments, and as far as researchers know there is a shortage in studies that specifically talked about scientific research for students in Libyan universities.

\section{Recommendations}

i. Training the graduate student on scientific research skills in what is related to all of his fields, as well as how to write, present and interpret results, proposals and recommendations, and what are the best ways to document references by adding a course for masters and doctorate students that specializes in the basics of scientific research and methods of writing it in the scientific way.

ii. Working to add a subject that is recorded and calculated during the thesis preparation hours, so that it can be studied as a discussion group for the messages that are prepared by registered students, and work to ensure that the number of students is not large in each of the lessons being created, due to the ease of understanding.

iii. Work to establish a special and independent department for scientific publishing in Libyan universities to facilitate the publication of research and scientific results for students in the best scientific journals.

\section{References}

Abdullah, A., \& Shamas, S. M. (2010). Obstacles of scientific research in the faculties of education from the point of view Faculty Members (Field study - College of Education in Salalah as a model). Damascus University Journal. Vol 26(1-2). PP 17-59.

Al Sharif, M. A. (2019). The Quality of Applied Scientific Research in Libyan Universities: Realities and Challenges the future. Faculty of Arts Journal. Vol 1. Issue 2. PP 140-163.

Algadheeb, N. A., \& Almeqren, M. A. (2014). Obstacles to Scientific Research in Light of a Number of Variables. Journal of International Education Research. Volume 10 (2). PP 101-110.

Alhrahsha, M. A. (2013). Scientific Research Barriers Facing Faculties at AL al-Bayt University. Association of Arab Universities Journal for Education and Psychology. Vol 11(3). PP 157-180.

Al-Khawaldeh, T. M., \& Magableh, A. Y. (2013). Obstacle Level Facing Jordanian Teachers in Conducting Scientific Research. Educational and Psychological Sciences Journal. Vol 14 (1). $71-$ 100.

Almaghribi, A. A. (2011). Problems facing students in the field of research in the Islamic and Comparative Education Department, Faculty of Education, Umm Al-Qura University. Master Thesis. Faculty of Education. Umm Al Qura University. Saudi Arabia.

Al-Shaibani, S. M. (2018). The reality of scientific research in the Arab world and its challenges in Libya. Journal of the faculty of aladab. Issue 25. the first part. PP 40-57.

Amer, A. A. (2018). The attitudes of the research professors towards publishing their scientific researches on the Internet, Faculty of Arts, University of Sabratah, as a model. Journal of the faculty of aladab. Issue 25. the first part. PP 120-146.

Bin Saud, R. M. (2014). The Non-Traditional challenges of scientific research in Libya and ways to methods of treatment. First International Conference Developing Scientific Research in Higher Education. 11-13 August. Oman. Jordon. 
INTERNATIONAL JOURNAL OF ACADEMIC RESEARCH IN BUSINESS AND SOCIAL SCIENCES

Vol. 10, No. 6, June, 2020, E-ISSN: 2222-6990 @ 2020 HRMARS

Droubi, W. H. (2018). The obstacles of scientific research in management information system and IT from the point view of researchers in Jordan universities. Aggregates of knowledge journal. Volume 4, Issue 1. PP 9-25.

El-Farra, M. M. (2004). Difficulties Facing Academic Scientific Research in the Faculties of Commerce in Gaza Governorates: From the point of view of faculty members. Journal of the Islamic University. Volume 12 (1). 1-35.

George, D., \& Mallery, P. (2003) SPSS for windows step by step: A sample Guide \& reference Boston; Allyn \& Bacon.

Hatamleh, H. M. (2016). Obstacles of Scientific Research with Faculty of University of Jadara from Their Point of View. Journal of Education and Practice, 7(33), 32-47.

Isaac, S., \& Michael, W. B. (1995). Handbook in Research and Evaluation. San Diedo, C. A: Educational and Industrial Training Services.

Krejcie, R. V., \& Morgan, D. W. (1970). Determining Sample Size for Research Activities. Educational and Psychological Measurement, 30, 607-610. Libyan Audit Bureau (2014), General Report.

Muhaisen, A. A. (2011). Personal and non-personal obstacles to scientific research as perceived by faculty members in Palestinian universities in Gaza. The first scientific conference: scientific research concepts, ethics, employment 10-11 May 2011. Islamic University of Gaza. PP 385435.

Perneger, T. V., Courvoisier, D. S., Hudelson, P. M., \& Gayet-Ageron, A. (2015). Sample size for pretests of questionnaires. Quality of Life Research, 24(1), 147-151. https://doi.org/10.1007/s11136-014-0752-2. 